\title{
AGROECOLOGICAL SOIL STATUS IN AGROECOSYSTEMS WITH MONOCULTURE
}

\author{
Valeriy Pinchuk ${ }^{1}$, Lyudmyla Symochko ${ }^{1,2^{*}}$, Nadiya Palapa ${ }^{1}$, Oleksiy Ustymenko ${ }^{3}$, \\ Olga Kichigina $^{1}$, Olena Demyanyuk ${ }^{1}$ \\ I*Institute of Agroecology and Environmental Management NAAS, \\ Metrologichna Str., 12, Kyiv, 03143, Ukraine; \\ ${ }^{2 *}$ Uzhhorod National University, Faculty of Biology, Voloshyna 32, Uzhhorod, \\ Transcarpathian region, 88000 , Ukraine; \\ ${ }^{3}$ Experimental Station of the Institute of Medicinal Plants of Institute of Agroecology and Environmental \\ Management of NAAS, 16-A Pokrovska Str, vill. Berezotocha, Lubny Poltava region, 35537, Ukraine;
}

*Corresponding author Lyudmyla Symochko, e-mail address: lyudmilassem @gmail.com;

Received November 2020; Accepted December 2020; Published January 2021;

DOI: https://doi.org/10.31407/ijees11.101

\begin{abstract}
The article presents original results of research. The dynamics of the balance and NPK use efficiency of the typical Ukrainian farm for monoculture cultivation during 2016-2018 has been calculated. Laboratory analysis of soil $(\mathrm{pH}$ value, humus content, $\mathrm{N}, \mathrm{P}_{2} \mathrm{O}_{5}$ and $\mathrm{K}_{2} \mathrm{O}$ ) and grain ( $\mathrm{N}$ and $\mathrm{P}_{2} \mathrm{O}_{5}$ content) was conducted in 2019. The negative dynamics of basic nutrient balance in the soil was revealed for 2016-2018 (nitrogen deficiency ranged from -30,6 to $-130,9 \mathrm{~kg} / \mathrm{ha} /$ year, phosphorus - from $-25,8$ to $-62,4 \mathrm{~kg} / \mathrm{ha} /$ year, potassium - from $-34,3$ to $-244,5 \mathrm{~kg} / \mathrm{ha} / \mathrm{year}$ ) and intensive pressures on the soil (NUE $=77,0-260,3 \%$, PUE $=171,3-1902,3 \%$ and KUE $=115,8-1429,8 \%$ ). Soil $\mathrm{pH}$ was found on average 5,6 (category: close to neutral), the nitrogen content averaged $99 \mathrm{mg} / \mathrm{kg}$ (very low level), $\mathrm{P}_{2} \mathrm{O}_{5}$ content $-208 \mathrm{mg} / \mathrm{kg}$ (high level) and $\mathrm{K}_{2} \mathrm{O}-119 \mathrm{mg} / \mathrm{kg}$ (medium level) on the farmland areas. The ratio between nitrogen, phosphorus and potassium content in the soil of the studied land areas on average reaches 1:0,9:1,2 while the scientifically sound norm is 1:0,9:0,8. The average humus content is $1,93 \%$ (low level). The calculated indicators of nitrogen and NUE balance only in 2017 met the recommended standards of the UN Economic Commission for Europe. The PUE and KUE values in 2016 exceeded the average rate of phosphorus and potassium removal from the soil - 22 and 12 times, respectively. Changes of acidity over the last three years indicate the acidification of the soil environment, which is quite natural: only nitrogenous mineral fertilizers are applied to the soil, which is physiologically acidic, soil liming is not carried out, the green manure crops are not sown, organic fertilizers are not applied, and in crop rotation was a monoculture. The widespread practice of plowing crop residues into the soil without applying phosphorus and potassium fertilizers for three years does not meet the crop requirements for phosphorus and potassium and creates high one-way pressure on the soil. Consequently, relatively high sunflower and maize yields are generated from the existing high and medium content of these elements in the soil. The tendency of decreasing humus content in soil has been noticed.
\end{abstract}

Keywords: agroecosystem, soil, monoculture, fertility, sunflower, maize, NPK, nitrogen emission. 
International Journal of Ecosystems and Ecology Science (IJEES) https://doi.org/10.31407/ijees
Abstract

Volume 11, issue 1, 2021 https://doi.org/10.31407/ijees11.1

Vol. 11 (1): 13-18 (2021) 